\title{
ANALISIS KESESUAIAN LEMBAR KERJA PESERTA DIDIK (LKPD) BIOLOGI KELAS X YANG DIGUNAKAN MAN RANTAUPRAPAT KABUPATEN LABUHAN BATU
}

\author{
Nurul Azmi, Puji Prastowo, Maslena \\ Program Studi Pendidikan Biologi, FMIPA, Universitas Negeri Medan, Medan \\ Jl. Williem Iskandar Psr. V Medan Estate, Medan, Indonesia, 20221 \\ E-mail : nurulazmimarpaung96@gmail.com
}

\begin{abstract}
ABSTRAK
Penelitian ini bertujuan untuk mengetahui kelayakan Lembar Kerja Peserta Didik (LKPD) kelas X yang digunakan di MAN Rantauprapat, Kabupaten Labuhan Batu. Kelayakan berdasarkan isi, konstruksi, teknis penyajian, dan kegrafikan. Penelitian ini merupakan penelitian deskriptif, dengan menggunakan data kuantitatif. Analisis data dilakukan dengan menghitung persentase komponen kesesuaian Lembar Kerja Peserta Didik (LKPD). Hasil penelitian menunjukkan bahwa Lebar kerja Peserta Didik (LKPD) yang digunakan di kelas $\mathrm{X}$ MAN Rantauprapat memiliki tingkat kesesuaian yang tinggi dan sesuai dengan standar isi, teknis, kostruksi dan kegrafikan yang ditetapkan BSNP. Perolehan persentase skor rata-rata sebesar 90,16 \%., denga rincian 97,04\% pada aspek kelayakan isi, 85\% pada aspek konstruksi, 93,32\% pada aspek teknis dan 85,29 \% pada aspek kegrafikan. Berdasarka materi pokoknya Prokariota memperoleh skor rata-rata tertinggi (92,12\%), sedangkan rata-rata skor paling rendah diperoleh pada materi pokok Virus $(87,92 \%)$. Hal ini menunjukkan bahwa LKPD Biologi yang digunakan kelas X MAN Rantauprapat layak untuk digunakan.
\end{abstract}

Kata Kunci : LKPD, kelayakan isi, kostruksi, teknis, kegrafikan

\section{ABSTRACT}

This study aims to determine the feasibility of Student Work Sheet (LKPD) class $X$ used in MAN Rantauprapat, Labuhan Batu District. Feasibility based on content, construction, technical presentation, and kegrafikan. This research is descriptive research, using quantitative data. Data analysis is done by calculating the percentage of Components component of Student Work Sheet (LKPD). The result of the research indicates that the workspace of Student (LKPD) used in class X MAN Rantauprapat have a high level of conformity and in accordance with standard of content, technical, construction and kegrafikan set by BSNP. Obtained percentage average score of $90.16 \%$., $97.04 \%$ detail details on content feasibility aspects, $85 \%$ on construction aspects, 93.32\% on technical aspects and $85.29 \%$ on aspects of kegrafikan. Based on the principal matter Prokaryotes obtained the highest average score (92.12\%), while the lowest average score was obtained on Virus (87.92\%) subject matter. This indicates that LKPD Biology which is used X MAN MANUFACTURE class can be feasible to use.

Keywords: LKPD, feasibility of content, construction, technical and graphics

\section{Pendahuluan}

Perkembangan ilmu pengetahuan dan teknologi akan menjadikan perubahan di segala bidang. Salah satu bidang yang mengalami perubahan yaitu bidang pendidikan. Pendidikan merupakan salah satu sektor penting dalam pembangunan di setiap negara. Menurut UndangUndang No. 20 Tahun 2003 pendidikan merupakan usaha sadar dan terencana untuk mengembangkan segala potensi yang dimiliki peserta didik melalui proses pembelajaran.

Lembar Kerja Peserta Didik (LKPD) merupakan salah satu sarana untuk membantu dan mempermudah dalam kegiatan belajar mengajar sehingga akan terbentuk interaksi yang efektif antara peserta didik dengan pendidik dan juga meningkatkan aktifitas peserta didik dalam peningkatan prestasi belajar. Selain itu LKPD juga merupakan lembaran-lembaran berisi tugas yang harus dikerjakan oleh peserta didik, lembar kerja biasanya berupa petunjuk, langkah-langkah untuk menyelesaikan suatu tugas. sehingga LKPD yang digunakan oleh siswa harus mencapai KD.

Guru harus cermat dan memiliki pengetahuan dan keterampilan yang memadai pada saat membuat LKPD karena sebuah LKPD 
harus memenuhi paling tidak kriteria yang berkaitan dengan KD, indikator, tujuan, materi, evaluasi serta tercapai atau tidaknya sebuah KD oleh peserta didik. Seperti dalam peraturan pemerintah No. 19/2005 pasal 43 ayat (5): kelayakan isi, bahasa, penyajian, dan kegrafisan buku teks/LKPD pelajaran dinilai oleh BSNP atau tim yang di bentuk oleh mentri dan selanjutya ditetapkan dengan peraturan Menteri. Badan Standar Nasional Pendidikan (BSNP) merupakan lembaga independen yang menetapkan kelayakan buku teks/LKPD untuk digunakan di sekolah. Lembar kerja peserta didik (LKPD) yang baik isinya harus mencakup semua Standar Kompetensi (SK) dan Kompetensi Dasar (KD) sesuai dengan Standar Isi (SI), bentuk penyajian yang menarik, bahasa yang baku, dan ilustrasinya menarik dan tepat. Maka diharapkan proses belajar pembelajaran yang dilakukan oleh guru dan siswa bisa optimal dan mencapai Standar Kompetensi Lulusan (SKL).

Sarana belajar yang dapat dipergunakan untuk mengeksplorasi lingkungan sekitar adalah dengan lembar kerja peserta didik (LKPD). Peningkatan aktivitas siswa sulit terjadi dengan sendirinya oleh karena itu peran guru sangat diperlukan dalam menciptakan situasi belajar yang penuh dengan aktivitas siswa salah satunya dengan menggunakan lembar kerja peserta didik (LKPD). Lembar kerja peserta didik (LKPD) digunakan untuk membantu tumbuhnya kreativitas siswa agar dapat menjawab suatu permasalahan, sehingga dalam kegiatan pembelajaran siswa akan aktif mencari dan menemukan sendiri jawaban permasalahan sedangkan guru hanya sebagai motifator dan fasilitator.

Pengembangan berbagai bahan ajar saat ini telah banyak dilakukan oleh berbagai kalangan, baik guru ataupun percetakan buku untuk memenuhi kebutuhan pendidikan yang diharapkan pemerintah. Adapun hal tersebut juga dilakukan oleh peneliti untuk dapat mengembangkan Lembar Kegiatan Peserta Didik (LKPD) guna memenuhi kebutuhan pendidikan saat ini. Nurlaila (2013) menganalisis bahwa kelayakan konstruksi memiliki kualitas terendah dalam LKS se- Lhokseumawe.

Berdasarkan hasil observasi yang dilakukan di MAN Rantauprapat didapatkan bahwa
Rendahnya kualitas Lembar kerja Peserta Didik (LKPD) disebabkan karena LKPD yang diganakan sering tidak memperhatikan kelayakan isi, konstruksi, teknis dan penyajian. Hal ini membuat siswa mudah bosan, materi yang singkat tidak bisa menegaskan tujuan yang ingin disampaikan, tampilan buku LKPD kurang menarik sehingga tidak menimbulkan minat membaca bagi siswa, dan butiran-butiran soal yang ada kurang sesuai dengan materi dan tujuan kompetensi yang ingin dicapai.

Berdasarkan latar belakang tersebut, peneliti tertarik untuk melakukan penelitian dengan judul Analisis Kesesuaiaan Lembar Kerja Peserta Didik (LKPD) Biologi Kelas X Yang Digunakan MAN Rantauprapat Kabupaten Labuhan Batu Tahun Pembelajaran 2017/2018. Penelitian ini penting dilakukan Sebagai tolak ukur bagi peningkatan mutu Lembar Kerja Peserta Didik (LKPD) Biologi yang digunakan sehigga dapat meningkatkan hasil belajar siswa.

\section{Metode Penelitian}

Penelitian ini dilakukan di MAN Rantauprapat, Kabupaten Labuhan Batu. Waktu penelitian dilaksanakan pada bulan Juni sampai November 2017 dengan pengambilan data dilakukan pada bulan September 2017. Populasi dan sampel dalam penelitian ini adalah LKPD Biologi yang di gunakan di kelas $X$ MAN Rantauprapat Kabupaten Labuhan Batu. Penelitian ini merupakan penelitian deskriptif, dengan pendekatan kuantitatif. LKPD yang dianalisis kesesuaiannya adalah LKPD yang digunakan di kelas X MAN Rantauprapat Kabupaten Labuhan Batu yaitu: sesuai dengan kelayakan isi, syarat teknis, syarat konstruksi dan kegrafikan.

Berdasarkan kelayakan isi aspek yang di ukur adalah 1). Kesesuaian dengan KD (kompetensi dasar) kurikulum 2013 (keluasan materi, kedalaman materi), 2). Keakuratan materi (keakuratan fakta da konsep), 3). Kemutakhiran materi (kesesuaian materi dengan perkembangan biologi, mendorong keingintahuan) 4). Dimensi keterampilan (relevan dengan tujuan, prosedur kerja akurat, aplikasi keterampilan dan kewirausahaan, kesehatan dan keselamatan kerja) 
5). Ketaatan pada hukum dan perundangundangan (ketaan terhadap hakii bebas dari sara/pornografi)

Berdasarkan kelayakan konstruksi aspek yang diukur adalah 1). Kesesuaian dengan perkembangan peserta didik, 2). Struktur kalimat, 3).Tata urutan pelajaran 4). Pertanyaan yang sesuai, 5). Sumber buku, 6). Ruangan (tempat menjawab soal), 7). Ilustrasi, 8). Tingkat penggunaan buku, 9). Tujuan belajar, 10). Identitas buku.

Berdasarkan kelayakan teknis aspek yang diukur adalah 1). Keakuratan tulisan (menggunakan huruf cetak, menggunakan huruf tebal yang agak besar untuk topik, menggunakan tidak lebih dari 10 kata dalam 1 baris, menggunakan bingkai untuk membedakan kalimat perintah dengan jawaban peserta didik, mengusahakan agar perbandingan besarnya huruf dengan besarnya gambar serasi, penulisan nama ilmiah atau asing dengan benar dan tepat). 2). Keakuratan gambar/ ilustrasi (Gambar dapat menyampaikan pesan atau isi dari gambar tersebut secara efektif kepada pengguna LKPD. Gambar dapat memperlihatkan kejelasan isi atau pesan dari gambar secara keseluruhan, Ilustrasi yang diberikan sesuai dengan fakta dan konsep Biologi, Gambar dilengkapi dengan keteragan-keterangan yang tepat, llustrasi dilengkapi dengan sumber yang jelas)

Berdasarkan kelayakan kegrafisan aspek yang diukur adalah 1). Ukuran (Kesesuaian ukuran buku, kesesuaian ukuran dengan materi isi buku) 2). Tata letak Kulit (Penataan unsur tata letak pada kover muka, belakang dan punggung memiliki kesatuan (unity), penataan tata letak pada kover muka, belakang dan punggung sesuai/harmonis dan memberikan kesan irama yang baik, menampilkan pusat pandang (center point) yang baik dan jelas, komposisi tata letak (judul, pengarang, ilustrasi, logo, dan lain-lain.) seimbang dan seirama dengan tata letak isi, ukuran unsur tata letak proporsional dengan ukuran, warna unsur tata letak harmonis dan memperjelas fungsi (materi isi, memiliki kekontrasan yang baik, penampilan unsur tata letak konsisten, penempatan unsur tata letak konsisten dalam satu seri). 3). Tipografi cover (Huruf yang digunakan menarik dan mudah dibaca, warna judul buku kontras daripada warna latar belakang, ukuran huruf proporsional dibandingkan ukuran) 4). Ilustrasi cover (Ilustrasi dapat menggambarkan isi/materi ajar, ilustrasi mampu mengungkap karakter objek, bentuk, wana, ukuran secara proporsional sesuai realita objek).

Data yang diperolah dianalisis dengan menggunakan rumus $\% \mathrm{x}_{i n=} \frac{\mathrm{zS}}{\mathrm{S}_{\mathrm{maks}}} \times 100 \%$

(Sudjana, 2005). Interpetasi jawaban dikategorikan sebagai berikut: Sangat tinggi: (80-100), Tinggi: (6080), Sedang: (40-60), Rendah: (20-40), Sangat rendah: $(0,0-20)$.

\section{Hasil penelitian}

Analisis Lembar Kerja Peserta Didik (LKPD) Biologi kelas X MAN Ratauprapat melibatkan tiga aspek yaitu kelayakan isi, penyajian, dan konstruksi Lembar Kerja Peserta Didik (LKPD). Hasil penelitian yang diperoleh, menunjukkan bahwa rata-rata kesesuaian dengan Lembar Kerja Peserta Didik (LKPD) Biologi kelas X MAN Rantauprapat berdasarkan kelayakan isi, konstruksi, teknis dan kegrafikan sebesar $90,16 \%$. Skor tertiggi diperoleh dari aspek kelayakan isi $(97,04)$ sedangkan skor terendah berasal dari aspek konstruksi (85,00 \%). Hal tersebut dapat dilihat dalam diagram dibawah ini. 


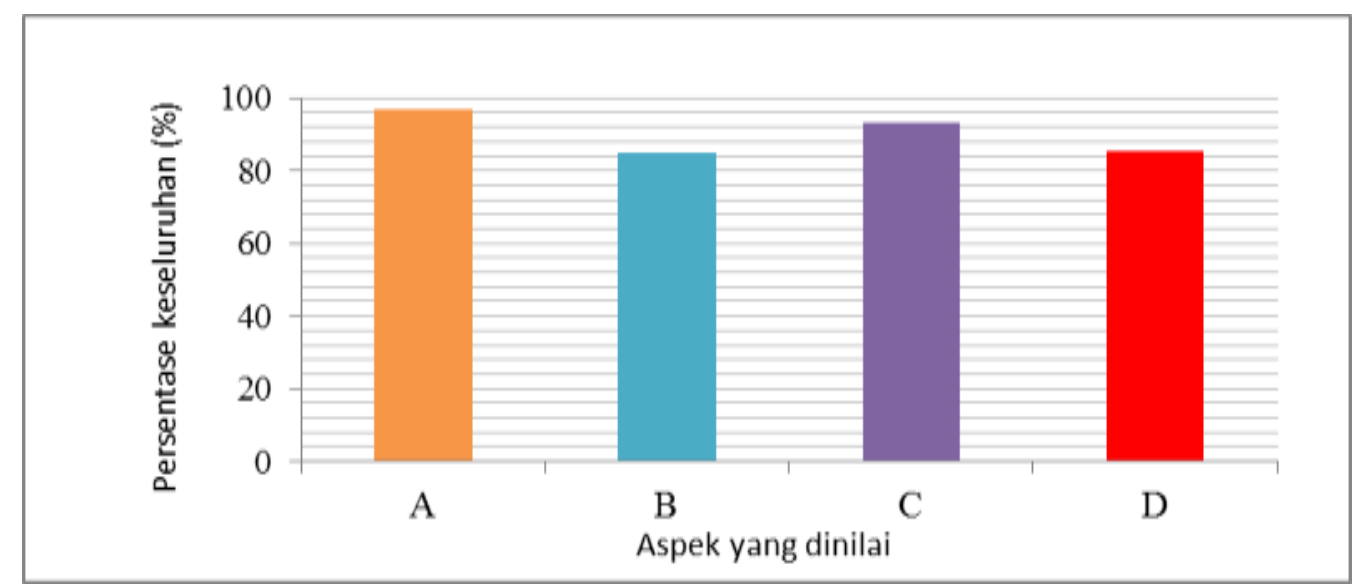

Gambar 1: Diagram hasil analisis Lembar Kerja Peserta Dididik (LKPD) Biologi Kelas X MAN Rantauprapat. Keterangan: A. Kelayakan Isi, B. Kelayakan Konstruksi, C. Kelayakan Teknis, D. Kelayakan Kegrafikan

Berdasarkan materi yang disajikan, LKPD dengan skor tertinggi untuk keempat aspek yang diukur adalah LKPD pada materi Prokariota $(92,12$
$\%)$, sedangkan LKPD yang terendah diperoleh pada materi Virus (87,92\%). Hal tersebut dapat dilihat pada diagram dibawah ini.

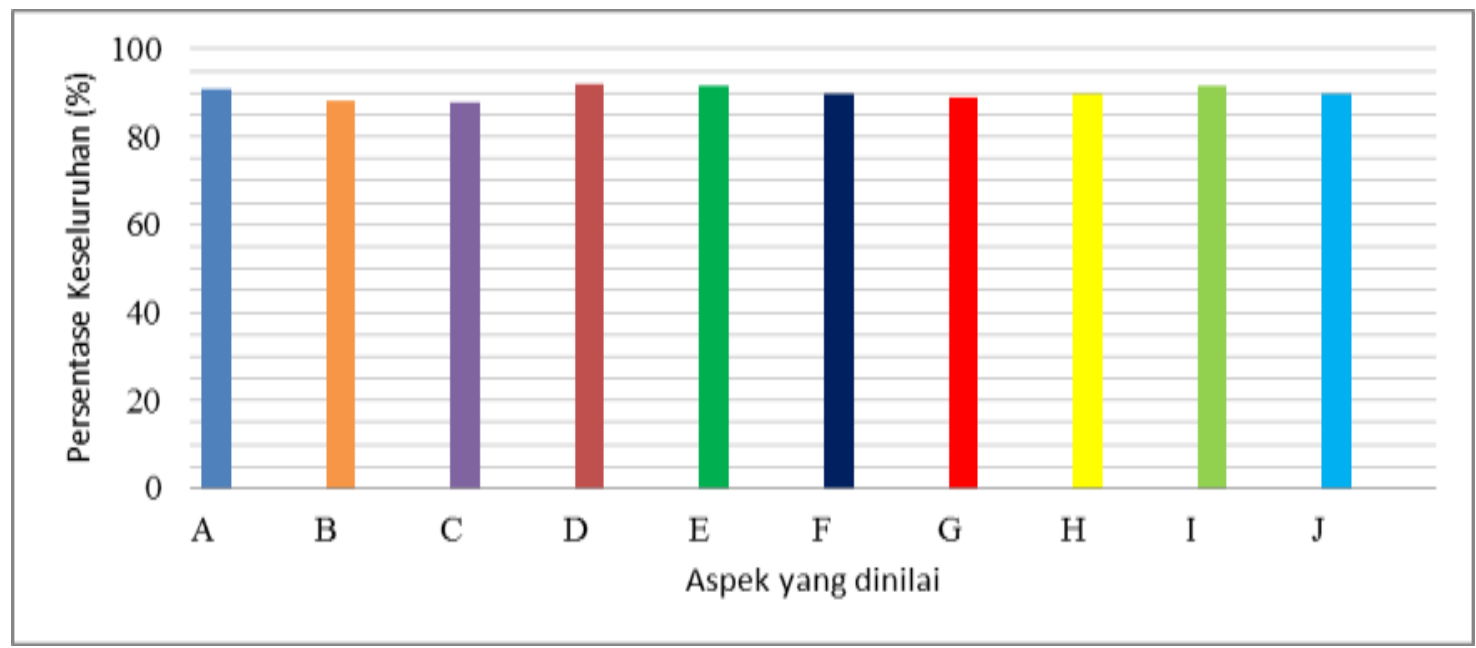

Gambar 2. Diagram hasil analisis Lembar Kerja Peserta Dididik (LKPD) Biologi Kelas X MAN Rantauprapat permateri. Keterangan : A. Biologi Sebagai Ilmu, B. Keanekaragaman Hayati, C. Virus, D. Prokariota, E. Protista, F. Fungi, G. Kingdom Plantae, H. Kingdom Animalia, I. Ekosistem, J. Pencemaran lingkungan

\section{Pembahasan}

Hasil penelitian menunjukkan bahwa dari tiga aspek penelitian yaitu kelayakan isi, konstruksi, penyajian, dan kegrafikan persentase tertinggi pada aspek kelayakan isi dan yang terendah adalah teknis konstruksi. Berdasarkan kelayakan isi LKPD Biologi di kelas X MAN Rantauprapat didapatkan persentase keseluruhan sebesar 97,04\% sehingga secara secara keseluruhan dikategorikan sangat baik. Dalam LKPD ini, Isi yang disajikan sudah sesuai dengan KI dan KD Biologi dan indikator yang telah ditetapkan BNSP. Kesalahan terbanyak berasal dari aspek konstruksi hal ini dikarenakan LKPD ini hanya berfokus pada materi, susunan bahasa, kosakata, tingkat kesukaran dan kejelasan dalam LKPD.

Berdasarkan kelayakan konstruksi LKPD Biologi di kelas X MAN Rantauprapat didapatkan persentase keseluruhan sebesar $85 \%$ sehingga secara keseluruhan dikategorikan sangat baik. Dalam LKPD ini aspek konstruksi merupakan yang terendah. Komponen yang tertinggi dalam aspek 
ini adalah kesesuaian dengan pekembangan peserta didik dan tata urutan pelajaran sedangkan komponen terendah adalah identitas buku. LKPD ini hanya berfokus pada materi yang ada tanpa memperhatikan susunan bahasa, kosakata, tingkat kesukaran dan kejelasan dalam LKPD padahal Melalui bahasa yang baik dan benar semua pesan dan informasi yang akan disampaikan oleh buku ajar atau buku teks tersebut dapat tersampaikan secara tepat.

Berdasarkan kelayakan teknis LKPD Biologi di kelas $X$ MAN Rantauprapat didapatkan persentase keseluruhan sebesar 93,40 \% sehingga secara keseluruhan dikategorikan sangat baik. Untuk aspek teknis, komponen tertinggi adalah menggunakan huruf cetak, Menggunakan huruf tebal yang agak besar untuk topik,Menggunakan bingkai untuk membedakan kalimat perintah dengan jawaban peserta didik, Gambar dapat menyampaikan pesan atau isi dari gambar tersebut secara efektif kepada pengguna LKPD, Ilustrasi yang diberikan sesuai dengan fakta dan konsep Biologi, Gambar dilengkapi dengan keteraganketerangan yang tepat sedangkan komponen terendah adalah sumber dari ilustrasi.

Berdasarkan kelayakan kegrafisan LKPD Biologi di kelas X MAN Rantauprapat didapatkan persentase keseluruhan sebesar 85,29 \% sehingga secara secara keseluruhan dikategorikan sangat baik. Pada kelayakan kegrafikan skor terendah terdapat pada bagian ilustrasi kover buku. Pada penilaian kelayakan kegrafikan ini dinilai secara keseluruhan dalam satu buku tidak seperti kelayakan isi, Konstruksi dan Teknis yang dinilai perbabnya. Ukuran LKPD ini adalah 210 mm x 297 $\mathrm{mm}$. Tata letak kulit buku dan tipografi kulit buku memiliki skor tertinggi sedangkan yang terendah adalah ilustrasi cover buku. cover buku tidak menunjukkan bahwa isi yang ada didalammnya adalah buku Biologi misalnya ada unsur mahluk hidup seperti hewan atau tumbuhan yang menandakan bahwa LKPD ini adalah LKPD Biologi. Ilustrasi yang ada pasa kover adalah gambar sebuah tablet yang apabila judul buku ditiadakan terlihat seperti buku TIK.

\section{Kesimpulan}

LKPD Biologi kelas $X$ Biologi di MAN Rantauprapat sudah layak untuk digunakan dari segi kelayakan isi, konstruksi, teknis, dan kegrafikan. Hal ini ditunjukkan dengan diperoleh rata-rata keseluruhan sebesar 90,16\%. Dengan rincian kelayakan isi diperoleh nilai besar 97,04\%. Kelayakan konstruksi diperoleh nilai besar 85,00\%. Kelayakan teknis diperoleh nilai besar 93,32\%. Kelayakan kegrafikan pada diperoleh nilai besar $85,29 \%$ sehingga secara keseluruhan sangat baik dan dapat digunakan dalam proses belajar mengajar.

\section{Daftar Pustaka}

Arikunto, S. 2013. Dasar-Dasar Evaluasi Pendidikan. Edisi Dua Cetakan Ketiga. Jakarta: Bumi Aksara.

BNSP. 2006. Buku panduan penyusunan KTSP. Jakarta : BNSP

BNSP. 2014 . penilaian buku teks pelajaran. Jakarta : BNSP

Darmodjo, H., dan Kaligis, R.E J. 1992. Pendidikan IPA II. Jakarta: Depdikbud

Depdiknas. 2008. Panduan Pengembangan Materi Pembelajaran dan Standar Sarana dan Prasarana. Jakarta: BP. Mitra Usaha Indonesia

Kementerian Pendidikan dan Kebudayaan Republik Indonesia.2012. Dokumen Kurikulum 2013. Jakarta : Kemendigbud.

Mulyasa, E. 2014. Pengembangan dan Implementasi Kurikulum 2013. Bandung: PT Remaja Rosdakarya.

Nurlaila. 2014. Analisis Kesesuaian Lembar Kerja Siswa (LKS) Biologi Sma Negeri SeKota Lhokseumawe Kelas XI Berbasiskan Standar Isi KTSP. Jurnal. Medan: Program Pasca sarjana UNIMED

Prastowo, A. 2011. Panduan Kreatif Membuat Bahan Ajar Inovatif. Yogyakarta: DIVA Press

Putri, A dan Lepiyanto, A. 2016. Pengembangan Lembar Kegiatan Peserta Didik (LKPD) Berbasis Scientific Approach Siswa SMA Kelas X Pada Materi Fungi. Jurnal Bioedukasi pendidikan Biologi Vol. 7. No 1. 
Halaman : $065-070$

Lampung: $\quad$ FMIPA Universitas

Muhammadiyah Metro

Undang-undang Republik Indonesia. 2003. Undang-undang Republik Indonesia Nomor 20 Tahun 2003 Tentang Sistem Pendidikan Nasional. Jakarta: Pemerintah Republik Indonesia.

Sudjana, N. 2005. Penilaian Hasi Proses Belajar Mengajar. Bandung: PT Remaja Rosdakarya

Sugiyono. 2012. Metode Penelitian Kuantitatif Kualitatif dan RND. Bandung: Alfabeta.

Peraturan Pemerintah Republik Indonesia. 2013. Peraturan Pemerintah Republik Indonesia Nomor 32 Tahun 2013 Tentang Perubahan Atas 5 /Peraturan Pemerintah Republik Indonesia Nomor 19 Tahun 2005 Tentang Standar Nasional Pendidikan. Jakarta: Pemerintah Republik Indonesia.

Poppy, KD. 2009. Pengembangan Perangkat Pembelajaran untuk Guru SMP. Bandung: PPPTK IPA

Trianto. 2007. Model Pembelajaran Terpadu dalam Teori dan Praktek. Jakarta: Prestasi Pusta Publis. 